\title{
Cholinergic Fibers and Muscarinic Receptors in the Central Auditory System
}

\author{
Satoko Hamada ${ }^{1,2) *}$, Stefan Trifonov ${ }^{2)}$, Takeshi Houtani ${ }^{2)}$, Masahiko Kase ${ }^{2)}$, Yuji Yamashita ${ }^{2)}$ \\ Kazuyasu Baba $^{1)}$, Jun-ichi Shimizu ${ }^{1,2)}$, Masato Maruyama ${ }^{2)}$, Koichi Tomoda ${ }^{1)}$ \\ Toshio Yamashita ${ }^{1)}$ and Tetsuo Sugimoto ${ }^{2)}$ \\ ${ }^{1)}$ Department of Otolaryngology and ${ }^{2)}$ Department of Anatomy and Brain Science, \\ Kansai Medical University, Moriguchi, Osaka 570-8506 Japan
}

\section{中枢聴覚系のコリン線維とムスカリン性受容体}

\author{
濱田＼cjkstart聡子1,2)*，ステファン トリフォノフ 2)，宝谷 剛志 ${ }^{2)}$ ，加瀬 政彦2) \\ 山下 雄司 ${ }^{2)}$, 馬場 一泰 ${ }^{1)}$, 清水 順一 ${ }^{1,2)}$, 丸山 正人 ${ }^{2)}$ \\ 友田 幸一1)，山下 敏夫 ${ }^{1)}$ ，杉本 哲夫2) \\ 1)関西医科大学大学院高次機能制御系耳鼻咽喉科学 \\ 2) 関西医科大学大学院高次機能制御系脳構築学
}

Received 8 July, 2011 / Accepted 29 July, 2011

\begin{abstract}
:
It was reported that central auditory dysfunction was evident in subjects with even mild cases of Alzheimer's disease. Major auditory stations in diseased brain manifested marked degenerative changes. This communication briefly summarized our morphological data on the distribution of cholinergic fibers and receptors in the ascending auditory stations of mouse brain. We revealed considerable involvements of $\mathrm{m} 2$ and $\mathrm{m} 3$ muscarinic receptors in several auditory stations, providing some morphological support for the cholinergic projections and receptors available to the auditory system.
\end{abstract}

Keywords: Cholinergic fibers, Muscarinic receptors, Auditory stations, Vesicular acetylcholine transporter, Nucleus of the brachium of the inferior colliculus, Auditory-visual communication

要旨:

アルッハイマー病では中枢聴覚系の機能障害を示唆する症状を合併する場合が少なくないまた細胞変性等の 病変が疾病脳の聴覚上行路各部位にも確認されている. 本研究ではマウス脳のこれらの部位に打けるコリン線維 とムスカリン性受容体 (m2, m3 タイプ) の発現分布密度を測定した. 聴覚上行路諸核で，これらコリン線維・ 受容体を介する情報伝達・変換が聴覚の伝達に一定の意義を有することが, 本研究から強く示唆された.

キーワード：コリン線維，ムスカリン性受容体，聴覚経路，小胞アセチルコリントランスポーター, 下丘腕核, 聴覚・視覚機能連関

The processing of sound information by the neurons of the central auditory system, initiating from the cochlear hair cells, is under constant modulation of their inhibitory and excitatory projection systems. There are several lines of evi- dence that cholinergic fibers, forming cholinergic synapses with these neurons, might modulate sound processing in the central auditory stations via typical cholinergic receptors, coupling it with behavioral arousal, attention and cognitive 
Satoko Hamada, et al..

Table 1. Distribution of relative densities of VAChT-positive fibers, $\mathrm{m} 2$ and $\mathrm{m} 3$ receptors in central auditory stations

\begin{tabular}{lccc}
\hline & VAChT & m2 receptor & m3 receptor \\
\hline Auditory cortex & + & ++ & ++ \\
Ventral nucleus of the medial geniculate body & + & ++ \\
Nucleus of the brachium of the inferior colliculus & + & + & + \\
Dorsal cortex of the inferior colliculus & +- & +- & + \\
Central nucleus of the inferior colliculus & +- & ++ \\
External cortex of the inferior colliculus & ++ & +- \\
Ventral cochlear nucleus & +- & ++ \\
Dorsal cochlear nucleus & +
\end{tabular}

Relative densities presented as: ++, high; +, moderate; +-, low.

functions. This communication briefly summarizes our morphological data on the distribution of cholinergic fibers and receptors in the ascending auditory stations of mouse brain.

Vesicular acetylcholine transporter (VAChT) is synthesized in most of the cholinergic neurons and is delivered to synaptic vesicles located at or near the axon terminals. Therefore, we have used VAChT immunohistochemistry for visualizing cholinergic fiber varicosities and to identify cholinergic axon terminals. We have elucidated cholinergic axon terminals in the pontine nuclei and precerebellar nuclei by means of VAChT immunohistochemistry ${ }^{1)}$. The results obtained at both light and electron microscopic levels strongly suggested regulatory roles of cholinergic pedunculopontine system on the neocortical input to the pontocerebellar projection fibers.

The $\mathrm{m} 2$ and $\mathrm{m} 3$ muscarinic receptors represent major cholinergic receptors in the neurons of the central auditory stations. Studies of the cellular effects revealed characteristic properties of these two subtypes. The $\mathrm{m} 2$ receptors are localized presynaptically and have inhibitory effect on the synthesis of cAMP. The $\mathrm{m} 3$ receptors are localized postsynaptically and are coupled to activation of phosphatidyl inositol turnover. In situ hybridization was used to delineate the distribution of neurons expressing the $\mathrm{m} 2$ and $\mathrm{m} 3$ receptors in the brainstem auditory nuclei and auditory cortex. The procedures are essentially the same as previously described $^{2,3)}$. Digoxigenin-labeled RNA probes for $\mathrm{m} 2$ and $\mathrm{m} 3$ receptors were prepared according to specific nucleotide sequences located at the third cytoplasmic loop, corresponding to the region of low amino acid homology between muscarinic receptor subtypes (for detailed description of the protocol, see ref.4).

The data obtained by in situ hybridization and immunohistochemistry in each auditory station was converted into relative density of labeled elements by means of image anal- ysis software and the values were reduced to three grades (Table 1). The VAChT-immunolabeled varicose fibers were seen in all auditory stations. The ventral cochlear nucleus has the highest level of accumulation of VAChT labeled terminals and the inferior colliculus has the lowest level. The $\mathrm{m} 2$ receptors were expressed at high levels in most of the auditory stations except for the central nucleus of the inferior colliculus and the ventral cochlear nucleus. The $\mathrm{m} 3$ receptors were expressed at very high level at the auditory cortex. Moderate expression of $\mathrm{m} 3$ receptor could be seen at the ventral nucleus of the medial geniculate body, nucleus of the brachium of the inferior colliculus, dorsal cortex of the inferior colliculus and the dorsal cochlear nucleus and low expression at the remaining parts of the inferior colliculus and the ventral cochlear nucleus.

The density of distribution of cholinergic receptor subtypes suggests that the cholinergic neurotransmission in the auditory cortex is mediated predominantly by the $\mathrm{m} 3$ receptors, while in the ventral nucleus of the medial geniculate body and nucleus of the brachium of the inferior colliculus, the $\mathrm{m} 2$ receptors are presumably dominant in the transduction of cholinergic signals.

The nucleus of the brachium of the inferior colliculus is involved in the processing of spatial auditory information in close association with the projections to and from the neurons of the deep layer of the superior colliculus, a visuomotor brainstem station ${ }^{5}$. From the present results, it should be emphasized that cholinergic fibers and receptors, especially the $\mathrm{m} 2$ type, could be involved in this bidirectional projection system (Fig. 1). Pharmacophysiological studies will be needed to examine if drugs that interact with $\mathrm{m} 2$ receptors may directly affect this auditory-visuomotor communication system.

In Alzheimer's disease, central auditory dysfunction was evident in even mild cases ${ }^{6,7)}$. In agreement with central 


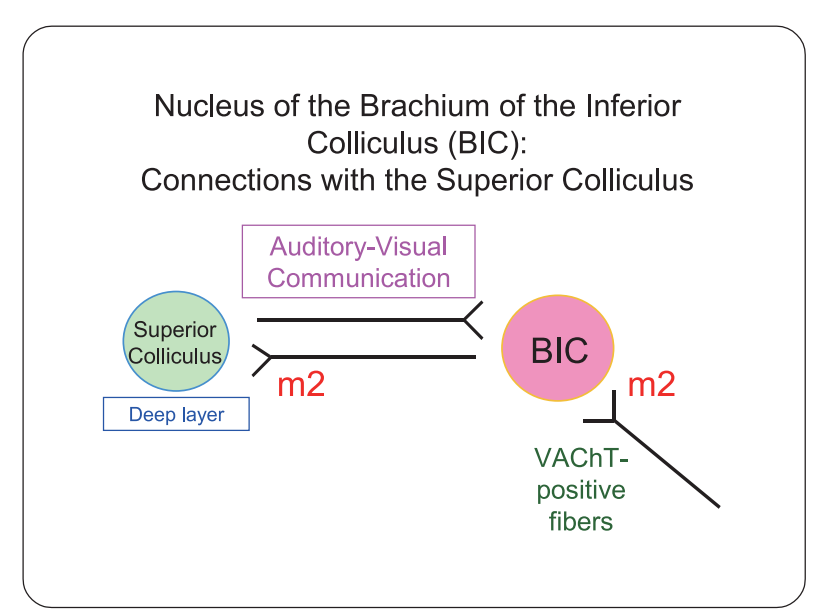

Fig. 1. The neurons of the nucleus of the brachium of the inferior colliculus (BIC) code auditory space in connection with superior colliculus neurons. The latter neurons are present in the deep layer and control visuomotor function. Our present results indicate an involvement of $\mathrm{m} 2$ muscarinic receptors in these connections.

auditory dysfunction, the primary auditory cortex, the ventral nucleus of the medial geniculate body and major auditory brainstem sites in diseased brain manifested marked degenerative changes ${ }^{8,9)}$. Neuroplastic responses of higher auditory centers become evident following impairment of cochlear hair cells. These deteriorative changes may culminate in hyperacusis and tinnitus of central type ${ }^{10)}$. The mechanism underlying these pathophysiological processes is likely to be associated with subcortical extra-auditory connections to the amygdala $^{11)}$ and visuomotor brainstem stations (Fig. 1). Our present findings support morphological evidence for the cholinergic projections and receptors available to the auditory system.

\section{Acknowledgements}

This communication was based on the thesis article (S.H.) and its oral presentation, to which the Award of the Medical Society of Kansai Medical University was given at the 10th Annual Meeting held on 18 March 2011. Supported in part by the grants from Science Research Promotion Fund of the Japan Private School Promotion Foundation.

\section{References}

1. Tsutsumi T, Houtani T, Toida K, Kase M, Yamashita T, Ishimura $\mathrm{K}$ and Sugimoto $\mathrm{T}$. Vesicular acetylcholine transporterimmunoreactive axon terminals enriched in the pontine nuclei of the mouse. Neuroscience 146: 1869-1878, 2007.

2. Trifonov S, Houtani T, Hamada S, Kase M, Maruyama M and Sugimoto T. In situ hybridization study of the distribution of choline acetyltransferase mRNA and its splice variants in the mouse brain and spinal cord. Neuroscience 159: 344-357, 2009.

3. Trifonov S, Houtani T, Shimizu J, Hamada S, Kase M, Maruyama M and Sugimoto T. GPR155: Gene organization, multiple mRNA splice variants and expression in mouse central nervous system. Biochem Biophys Res Commun 398: 1925, 2010.

4. Hamada S, Houtani T, Trifonov S, Kase M, Maruyama M, Shimizu J, Yamashita T, Tomoda K and Sugimoto T. Histological determination of the areas enriched in cholinergic terminals and M2 and M3 muscarinic receptors in the mouse central auditory system. Anat Rec (Hoboken) 293: 13931399, 2010.

5. Wise LZ and Irvine DR. Auditory response properties of neurons in deep layers of cat superior colliculus. J Neurophysiol 49: 674-685, 1983.

6. Gates GA, Karzon RK, Garcia P, Peterein J, Storandt M, Morris JC and Miller JP. Auditory dysfunction in aging and senile dementia of the Alzheimer's type. Arch Neurol 52: 626-634, 1995.

7. Gold M, Lightfoot LA and Hnath-Chisolm T. Hearing loss in a memory disorders clinic. A specially vulnerable population. Arch Neurol 53: 922-928, 1996.

8. Ohm TG and Braak H. Auditory brainstem nuclei in Alzheimer's disease. Neurosci Lett 96: 60-63, 1989.

9. Sinha UK, Hollen KM, Rodriguez R and Miller CA. Auditory system degeneration in Alzheimer's disease. Neurology 43: 779-785, 1993.

10. Nelson JJ and Chen K. The relationship of tinnitus, hyperacusis, and hearing loss. Ear Nose Throat J 83: 472-476, 2004.

11. Møller AR. Pathophysiology of tinnitus. Otolaryngol Clin North Am 36: 249-266, v-vi, 2003. 